\title{
HUBUNGAN ANTARA PEMBANGUNAN INFRASTRUKTUR DAN KEMAMPUAN USAHA MASYARAKAT
}

\author{
Nanang Bagus Srihardjono \\ Program Studi Administrasi Publik Fakultas Ilmu Sosial \& Ilmu Politik \\ Universitas Tribhuwana Tunggadewi \\ Email: nanangbagus0341@yahoo.co.id
}

\begin{abstract}
The purpose of this study was to find out how the relationship between infrastructure development and community skills in the village of SuruhTembawang, EntikongSub-district, Sanggau District. The method used in this study was descriptive quantitative. The sample technique applied was a purposive sampling with a sample of 100 people. The data collection techniques invloved questionnaire and documentation. The sata analysis used regression, validity test, reliability test, correlation test. The results of the studyshowed that there was a strong relationship between infrastructure development and the community business capacity increasingat poin of $0.770(77 \%)$. While the direction of the relationship was positive because the value of $r$ was also positive.It meant that a better infrastructuredevelopment affected the improvement of business capacity of the community in SuruhTembawangvillage.
\end{abstract}

Keywords: Development; Infrastructure; Community Enterprises.

\begin{abstract}
Abstrak: Tujuan dari penelitian ini untuk mengetahui bagaiamana hubungan antara pembangunan infrastruktur dan kemampuan usaha masyarakat di desa Suruh Tembawang Kecamatan Entikong Kabupaten Sanggau. Metode yang digunakan dalam penelitian ini adalah deskriptif kuantitatif. Teknik sampel yang digunakan dalam penelitian ini adalah purposive sampling dengan jumlah sampel 100 orang. Teknik pengumpulan data menggunakan kueisoner dan dokumentasi. Teknik analisa data dalam penelitian ini menggunakan regresi, uji validitas, uji reliabilitas, uji korelasi. Berdasarkan hasil penelitian menunjukkan bahwa terjadi hubungan yang kuat antara pembangunan infrastruktur dan peningkatan kemampuan usaha masyarakat sebesar 0,770 (77\%). Sedangkan arah hubungan adalah positif karena nilai $r$ positif, berarti semakin baik pembangunan infrastruktur maka semakin baik peningkatan kemampuan usaha masyarakat di Desa suruh tembawang.
\end{abstract}

Kata Kunci: Pembangunan; Insfrastruktur; Usaha Masyarakat.

\section{PENDAHULUAN}

Pembangunan merupakan suatu usaha untuk merubah taraf kehidupan masyarakat menuju ke arah yang lebih baik dengan cara yang terencana, terukur, integral dan berkelanjutan dengan memperhtikan berbagai aspek dan kondisi kehidupan masyarakat serta berpegang pada dasar dan tujuan dari negara itu sendiri. Pembangunan merupakan suatu perwujudan dari kebijakan publik yang telah melalui suatu rangakaian panjang dan komprehensif dengan berbagai tahapan serta pertimbangan matang sebelum diputuskan agar tidak sekedar formalitas dari para pengambil kebijakan yang akan menimbulkan penolakan dan keresahan bagi masyarakat akibat kepentingan yang tidak berpihak bagi mereka sebagai subjek dari pembangunan itu sendiri.

Pembangunan (development) adalah proses perubahan yang mencakup seluruh sistem sosial, seperti politik, ekonomi, infrastruktur, pertahanan, pendidikan dan teknologi, kelembagaan, dan budaya. Pembangunan suatu daerah bertujuan untuk meningkatkan kesejahteraan dan mewujudkan keadilan sosial bagi seluruh lapisan masyarakat. Untuk itu pembangunan membutuhkan pendekatan yang tepat, guna menghasilkan pertumbuhan yang disertai pemerataan. 
Infrastruktur berperan penting dalam peningkatan investasi dan memperluas jangkauan partisipasi masyarakat, serta pemerataan hasil pembangunan. Pembangunan daerah selama ini hanya merupakan pendukung dari pembangunan nasional, dan mulai mengalami perubahan yang sesuai dengan keinginan yang berkembang di daerah hal tersebut menyebabkan pola pembangunan menjadi perubahan yang tidak beraturan (Sjafrizal, 2015: 19).

Pembangunan infrastruktur merupakan roda penggerak pertumbuhan ekonomi. Dari alokasi pembiayaan publik dan swasta, infrastruktur dipandang sebagai lokomotif pembangunan nasional dan daerah. Infrastruktur juga berpengaruh penting bagi peningkatan kualitas hidup dan kesejahteraan manusia, antara lain dalam peningkatan nilai konsumsi, peningkatan produktivitas tenaga kerja dan akses kepada lapangan kerja, serta peningkatan kemakmuran yang nyata. Infrastruktur juga memiliki pengaruh penting dalam peningkatan nilai konsumsi, peningkatan produktivitas tenaga kerja dan akses kepada lapangan kerja. Sifat dan jenis infrastruktur yang diperlukan suatu daerah dipengaruhi oleh karakteristik alam dan pola persebaran penduduk yang khas pada daerah tersebut.

Infrastruktur bukan hanya diperlukan untuk meningkatkan daya saing demi mendorong lebih banyak kegiatan investasi, produksi dan perdagangan, tetapi juga untuk mempercepat pemerataan pembangunan sehingga tingkat kemiskinan dan pengangguran dapat diturunkan. Infrastruktur seperti halnya sarana jalan, keberadaannya merupakan modernisasi bangsa yang penyediaannya merupakan salah satu aspek penting guna meningkatkan kelancaran produktivitas sektor produksi, dan yang tak kalah pentingnya infrastruktur jalan ini juga dapat berperan sebagai pendukung dalam menciptakan dan meningkatkan akses transportasi bagi masyarakat dalam beraktivitas.

Keberadaan infrastruktur fisik yang baik seperti hal nya jalan, jembatan, sarana telekomunikasi, sarana perlistrikan, sarana irigasi dan sarana transportasi juga sering dikaitkan sebagai pemicu perkembangan pembangunan di berbagai bidang pada suatu kawasan. Dengan mudah kita dapat menilai perbedaan kesejahteraan suatu kawasan hanya dengan melihat dari kesenjangan infrastruktur yang terjadi di dalamnya. Terkait dengan hal tersebut di atas, untuk itu kedepannya percepatan pembangunan infrastruktur semakin penting untuk lebih diperhatikan, hal ini didasarkan pada manfaat dari keberadaan infrastruktur seperti halnya jalan yang dapat berperan sebagai sarana pembuka keterisolasian suatu wilayah dari dunia luar sehingga dengan adanya infrastruktur ini, diharapkan berdampak pada peningkatan kesejahteraan masyarakat dalam bidang ekonomi dan kemampuan usaha.

Tujuan pembangunan pada dasarnya adalah untuk menciptakan kemajuan di bidang ekonomi dan kemampuan usaha secara berkesinambungan, tanpa mengabaikan persamaan hak dan menjunjung tinggi prinsip-prinsip keadilan bagi masyarakat Indonesia secara keseluruhan. Pembangunan infrastruktur termasuk ke dalam pembangunan fisik dan sudah sejak lama diketahui, bahwa keberadaan infrastruktur yang baik memiliki peran yang sangat penting dalam menunjang pemenuhan hak dasar masyarakat seperti pangan, sandang, papan, pendidikan dan kesehatan. Dengan demikian, dapat dikatakan bahwa infrastruktur merupakan modal yang sangat dibutuhkan masyarakat dalam mendukung kegiatan di berbagai bidang.

Di samping sebagai alat yang dapat menghubungkan antar daerah di indonesia, infrastruktur yang biasa sering disebut sebagai sarana dan prasarana fisik ini, memiliki keterkaitan yang kuat dengan laju pertumbuhan ekonomi suatu wilayah. Hal tersebut ditandai dengan wilayah yang memiliki kelengkapan sistem infrastruktur yang berfungsi lebih baik akan berdampak pada tingkat kesejahteraan sosial dan pertumbuhan ekonomi masyaraktanya. Pembangunan ekonomi atau kemampuan usaha merupakan sesuatu yang sangat penting bagi manusia, diperlukan aktivitas 
ekonomi atau kemampuan usaha masyarakat dalam menggerakan roda kehidupan masyarakat itu sendiri dalam situasi ini penting adanya peran masyarakat yang berkolaborasi langsung dengan pemerintah untuk kesejahteraan hidup masyarakat.

Instrument penting dalam peningkatan kemampuan usaha masyarakat yaitu infrastruktur, pembangunan infrastruktur yang baik dan merata akan sangat membantu keberhasilan usaha masyarakat khususnya masyarakat yg tingkat ekonominya rendah dan infrastrukturnya masih sangat terbatas pembangunan suatu daerah bertujuan untuk meningkatkan kesejahteraan dan mewujudkan keadilan sosial bagi seluruh lapisan masyarakat. Perlu adanya pembangunan di daerah tertinggal dikarenakan kondisi yang ada sekarang sangatlah buruk, besarnya APBN yang dianggarkan sangat diharapkan dapat meningkatkan rendahnya tingkat kehidupan masyarakat di daerah tertinggal yang sangatlah memprihatinkan, kondisi ini dapat dikatakan bahwa Pembangunan Nasional yang dilaksanakan selama lebih ini ternyata belum merata keseluruh wilayah serta dampaknya belum dirasakan oleh seluruh lapisan masyarakat, pembangunan selama ini hanya diperuntukkan pada masyarakat kota dan desa-desa yang ada di sekitarnya.

Pembangunan tidak pernah menyentuh daerah-daerah pedalaman dan masyarakat terpencil sehingga terjadi masyarakat yang maju akan terus maju sementara masyarakat tetinggal akan tetap saja tertinggal dan terbentuklah situasi kesenjangan sosial yang menyolok dimasyarakat Indonesia. Untuk itu pada wilayah perbatasan pembangunan infrastruktur sangatlah dibutuhkan yang tujuannya untuk peningkatan kemampuan usaha masyarakat daerah perbatasan disitulah akan terjadinya pemberdayaan masyarakat yang ditimbulkan dengan adanya pembangunan infrastruktur yang baik dan sesuai kebutuhan masyarakat daerah tersebut.

\section{HASIL PENELITIAN}

1. Uji Validitas instrumen dinyatakan valid jika $R_{\text {hitung }} \geq R_{\text {tabel. }}$

Berikut merupakan hasil uji validitas:

Tabel 1: Hasil Uji Validitas Data

\begin{tabular}{|c|c|c|c|c|}
\hline Variabel & pertanyaan & rtabel & rhitung & keterangan \\
\hline Pembangunan Infrastruktur & 1 & 0,195 & 0,754 & valid \\
\cline { 2 - 5 } & 2 & 0,195 & 0,896 & Valid \\
\cline { 2 - 5 } & 3 & 0,195 & 0,579 & Valid \\
\cline { 2 - 5 } & 4 & 0,195 & 0,643 & Valid \\
\cline { 2 - 5 } & 5 & 0,195 & 0,342 & Valid \\
\cline { 2 - 5 } & 6 & 0,195 & 0,491 & Valid \\
\hline Peningkatan Kemampuan Usaha & 7 & 0,195 & 0,815 & Valid \\
\cline { 2 - 5 } Masyarakat & 8 & 0,195 & 0,755 & Valid \\
\cline { 2 - 5 } & 9 & 0,195 & 0,765 & Valid \\
\cline { 2 - 5 } & 10 & 0,195 & 0,319 & Valid \\
\cline { 2 - 5 } & 11 & 0,195 & 0,732 & Valid \\
\cline { 2 - 5 } & 12 & 0,195 & 0,420 & Valid \\
\hline
\end{tabular}

Sumber: diolah peneliti, 2019

Berdasarkan hasil Uji Validitas semua instrumen dinyatakan valid karena nilai $\mathrm{R}_{\text {hitung }}$ lebih besar dari $\mathrm{R}_{\text {tabel }}(0.195)$.

2. Uji Reliabilitas instrumen di nyatakan Reliabel jika $R_{\text {hitung }} \geq R_{\text {tabel }}$

Berikut merupakan hasil uji reliabelitas

Tabel 2: Hasil Uji Reliabilitas Data 2019

\begin{tabular}{|l|c|c|}
\hline \multicolumn{1}{|c|}{ Kategori } & Nilai $(\alpha)$ & Keterangan \\
\hline Pembangunan infrastruktur & 0,680 & Reliable \\
\hline Peningkatankemampuanusahamasyarakat & 0,692 & Reliable \\
\hline
\end{tabular}

Sumber: diolah peneliti, 2019 
Berdasarkan hasil uji Reliabel kedua instrumen dapat dinyatakan Reliabel karena nilai Cronbach's Alpah dari kedua instrumen lebih besar dari $\mathrm{R}_{\text {tabel }}(0.195)$

3. Analisis Korelasi Linear Sederhana (Bivariate Correlation)

Digunakan untuk mengetahui ada atau tidak hubungan antara dua variabel dan juga untuk mengetahui seberapa erat hubungan antara dua variabel yang biasa disebut variabel independen (X) dan variabel dependen (Y). Koefisien relasi sederhana menunjukan seberapa besar hubungan yang terjadi antara dua variabel.

Tabel 3: Analisis Korelasi Linear Sederhana

\begin{tabular}{|c|c|c|c|c|}
\hline \multicolumn{5}{|c|}{ Correlations } \\
\hline & & & PI & PKUM \\
\hline \multirow[t]{3}{*}{ PI } & \multirow[t]{3}{*}{$X$} & Pearson Correlation & 1 &, $770^{* *}$ \\
\hline & & Sig. (2-tailed) & & , 000 \\
\hline & & $\mathrm{N}$ & 100 & 100 \\
\hline \multirow[t]{3}{*}{ PKUM } & \multirow[t]{3}{*}{$\mathrm{Y}$} & Pearson Correlation &, $770^{* * *}$ & 1 \\
\hline & & Sig. (2-tailed) &, 000 & \\
\hline & & $\mathrm{N}$ & 100 & 100 \\
\hline
\end{tabular}

Sumber: diolah peneliti, 2019

Dari tabel 3 dapat diketahui bahwa nilai pearson correlation sebesar 0,770 dengan nilai signifikan 0,000 . Hasil tersebut menunjukan bahwa variabel pembangunan infrastruktur dan peningkatan kemampuan usaha masyarakat mempunyai hubungan, karena 0,770 masuk interval 0,60-0,799 (Kuat).

\section{PEMBAHASAN}

Hasil yang mempengaruhi penelitian ini yaitu, data, dokumentasi dan survey lapangan adalah seizin dan sepengetahuan pemerintah kabupaten sanggau, kecamatan entikong, dan pemerintah desa suruh tembawang, serta izin dari ketua adat setempat yang membuat penelitian yang saya jalani priode 10 desember-10 januari telah selesai di laksanakan dan telah tuntas di input dalam sebuah hasil skripsi. Penelitian ini menggunakan dua variable $\mathrm{X}$ dan $\mathrm{Y}$ yaitu, variable $\mathrm{X}$ pembangunan infrastruktur kemudian variable Y peningkatan kemampuan usaha masyarakat. Dari kedua variable tersebut lahirlah indiKator-indikator penelitian yaitu indikator $\mathrm{X}$ (memajukan,memperbaiki, meningkatkan, usaha) yang di ambil dari teori Jamaludin, Adon Nasrullah (2016:6), pembangunan adalah upaya memajukan atau memperbaiki serta meningkatkan nilai sesuatu yang sudah ada. Pembangunan juga berarti seperangkat usaha manusia untuk mengarahkan perubahan bernegara, yaitu mencapai pertumbuhan peradaban sosial dan kebudayaan atas dasar-dasar target yang telah ditetapkan, dan variabel y dengan indikator (proses, penambahan keterampilan, pencapaian, target) yang diambil dari teori Menurut Adi S (2003:23), Yang berarti lapis atau lapisan dari sesuatu yang kemudian membentuk susunan. Tingkat juga dapat berarti pangkat, taraf, dan kelas. Sedangkan peningkatan berarti kemajuan. Secara umum, peningkatan merupakan upaya untuk menambah derajat, tingkat, dan kualitas maupun kuantitas. Peningkatan juga dapat berarti penambahan keterampilan dan kemampuan agar menjadi lebih baik. Selain itu, peningkatan juga berarti pencapaian dalam proses, ukuran, sifat, hubungan dan sebagainya.

Dengan adanya pembangunan infrastruktur maka taraf hidup masyarakat desa suruh tembawang berdasarkan hasil tanggapan dari responden $60 \%$ masyarakat menjawab setuju dengan 
adanya pembangunan infrastruktur yang dilakukan pemerintah daerah dari data tersebut dapat diartikan bahwa pwmbangunan infrastruktur penting untuk dilakukan karena sangat membantu bagi masyarakat desa suruh tembawang. Bukan hanya taraf hidup masyarakat saja yang terangkat melainkan kualitas hidup masyarakat juga terangkat dengan adanya pembangunan infrastruktur yang di bangun, mayarakat desa suruh tembawang sangatlah menanti pembangunan yang dirasakan saat ini karena masyarakat sangat merasa sekali bahwa infrastruktur yang di bangun sangatlah berdampak langsung bagi seluruh masyarakat desa suruh tembawang dari data lapangan bahwa $86 \%$ responden setuju bahwa pembangunan infrastruktur dilakukan di wilayahnya.

Setelah dibangunnya infrastruktur usaha masyarakat tumbuh dengan pesat dari data yang didapat dari responden di lapangan bahwa pendapatan masyarakat lebih banyak dari bidang usaha yakni dengan $79 \%$ responden menjawab setuju bahwa pembangunan infrastruktur sangatlah membantu pendapatan masyarakat desa suruh tembawang. Dengan usaha yang tumbuh begitu pesat di daerah tersebut maka dengan adanya infrastruktur yang baik maka kemauan masyarakat untuk berusaha semakintinggi lagi hal ini di dukung dari data responden yang menjawab bahwa 93\% masyarakat desa suruh tembawang merasa bahwa kemauan berusaha mereka meningkat dengan adanya infrastruktur itu sendiri dan tidak hanya mengharapkan alam lagi untuk memenuhi kebutuhan hidupnya.

Masyarakat desa suruh tembawang juga mengatakan bahwa sekarang mereka lebih mudah melakukan kegiatan usahanya masing-masing dan tidak adanya kendala lagi yang menghabat masyarakat untuk melakukan segala jenis dan bentuk usaha hal ini didukung dengan data responden sebesar $76 \%$ masyarakat setuju. Data responden juga menujukan bahwa $91 \%$ masyakatat menyetujui bahwa usaha yang masyarakat lakukan jadi sangat berkembang dengan adanya infrastruktur yang baik dan memadai dan masyarakat sangat berharap bahwa pembangunan akan terus berjalan dikarenakan bahwa masyarakat sangat membutuhkan sekali daerahnya untuk di bangun. Proses usaha saat ini sudahlah sangat baik dibuktikan dengan adanya benyak sekali usahausaha yang ada di desa suruh tembawang dari usaha rumahan/toko dan perkebunan bahkan usaha sebagai kerajinan dari alam, jadi dari data yang diperoleh di lapangan masyarakat merasa sangat mudah melakukan usaha karena akses yang semakin mudah bahkan segala sarana dan perasarana untuk menjual hasil usaha masyarakat sudah ada dan sangat membantu masyarakat, distribusi akan semakin cepat bahkan banyak memangkas biaya yang sangat besar sebelum adanya akses dan angkutan.

Dengan berbagai akses yang semakin mudah dan infrastruktur yang sudah ada data lapangan membuktikan bahwa masyarakat semakin terampil dalam berbagai bidang usahanya bahkan masyarakat menggunakan keterampilannya tersebut untuk lebih mengembangkan usahanya, data dari responden sangatlah menunjukan bahwa $66 \%$ responden mengatakan sangat setuju bahwa infrastrukturlah yang memberikan dampak besar untuk usaha masyarakat, ditambah lagi dengan mudahnya akses informasi dari luar daerah bahkan dengan dibangunnya pemancar sinyal membuat masyarakat lebih mudah lagi mengakses informasi bahkan dari luar negreri, hal inilah yang membuat masyarakat desa suruh tembawang semakin kreatif dan semakin semangat dalam menjalankan usaha. Kelancaran akses usaha juga sangat membantu masyarakat untuk memenuhi pencapaian penghasilannya disini tergantung masyarakatnya lagi apabila semakin kereatif dan membuat konsumen tertarik dan rajin dalam melakukan usaha di berbagai bidang maka pencapaian penghasilan pun akan sangat mudah dipenuhi.

Dari data lapangan juga menunjukan bahwa keterampilan yang ada di masyarakat juga akan sangat membantu memenuhi target usaha yang di penuhi hal ini di tunjukan dengan $86 \%$ responden menjawab setuju dan membuktikan bahwa dampak yang sangat baik dengan adanya 
pembangunan infrastruktur yang dilakukan oleh pemerintah. Apalagi diukung dengan usaha yang sekarang sangat mudah dilakukan dengan adanya infrastruktur maka target yang masyarakat inginkan untuk mendukung kelangsungan usaha dan hidupnya akan dengan mudah terpenuhi.dari semua data lapangan yang saya bahas didukung dengan data yang valid maka saya selaku peneliti dapat menyimpulkan bahwa adanya hubungan antara pembangunan infrastruktur dengan peningkatan kemampuan usaha masyarakat.

\section{KESIMPULAN}

Berdasarkan hasil penelitian dan pembahasan serta analisis perhitungan, dapat ditarik kesimpulan bahwa nilai pearson correlation sebesar 0,770 dengan nilai signifikan 0,000 yang menunjukan variabel pembangunan infrastruktur dan peningkatan kemampuan usaha masyarakat mempunyai hubungan, karena 0,770 masuk interval 0,60-0,799 (Kuat). Hubungan tersebut menunjukan bahwa pembangunan infrastruktur mempunyai hubungan dengan peningkatan kemampuan usaha masyarakat masyarakat di Desa Suruh tembawang. Berdasarkan hasil uii $\mathrm{T}$ yang di lihas dari tabel Anova, diperoleh nilai $\mathrm{T}_{\text {hitung, }}$, sebesar 448,505> $\mathrm{T}_{\text {tabel }}$ sebesar 3,94 dengan nilai signifikan (Sig) sebesar 0,000 $<0,05$ maka berarti Ho ditolak, sehingga dapat disimpulkan bahwa variabel terikat peningkatan kemampuan usaha Masyarakat dipengaruhi secara simultan oleh variabel bebas pembangunan infrastruktur.

\section{DAFTAR PUSTAKA}

Awandari, Indrajaya Bagus I Gusti. Pertumbuhan Ekonomi Terhadap Kesejahteraan Masyarakat Melalui Kesempatan Kerja. E-Jurnal EP Unud, 5 (12): 1435-1462, (https://ojs.unud.ac.id/index.php/eep/article/view/24308) 6 November 2018.

Bungin, Burhan. 2009. Metodologi Penelitian Kuantitatif. Yogyakarta: Kencana Prenada Media Group.

Creswell, John W. 2016. Reseacrh Design Pendekatan Metode Kualitatif, Kuantitatif, dan Metode Campuran. Yogyakarta: Pustaka Pelajar.

Darmawan, Deni. 2013. Metode Penelitian Kuantitatif. Bandung: PT. Remaja Rosdakarya.

Dwi Anggraini, Saryono. 2011. Metodologi Penelitian Kuantitatif. Bandung: Nuha Medica.

Hapsari, Tunjung. 2011. Pengaruh infrastruktur terhadap pertumbuhan ekonomi di Indonesia. (repository.uinjkt.ac.id) 6 November 2018.

Jamaludin, Adon Nasrullah. 2016. Sosiologi Pembangunan. Bandung: Pustaka Setia.

Nugraheni, D. 2012. Kinerja Keuangan Daerah, Infrastruktur, Kemiskinan: Analisis Kabupaten/Kota Di Indonesia 2006-2009. Skripsi. Fakultas Ekonomi dan Manajemen Institut Pertanian Bogor, Bogor.

Singgih, D. Gunarsa. 2015. Dasar-dasarteoriperkembangan.Jakarta: GunungMulia.

Sjafrizal, 2015. Perencanaan Pembangunan Dalam Era otonomi. Yogyakarta: Rajawali Press. Sugiyono. 2014. Metode Penelitian Kuantitatif, Kualitatif, dan $R \&$ D. Bandung: CV. Alfabeta. Suryono, Agus. 2010. Dimensi-Dimensi Prima Teori Pembangunan. Malang: Um-Press. Syani, Abdul. 2012. Sosiologi Skematika Teori dan Terapan. Jakarta: PT. Bumi Aksara. Tjokrowinoto, Moeljarto. 2007. Dilema Dan Tantangan. Yogyakarta: Pustaka Pelajar. Undang-Undang Nomor 20 Tahun 2008 Tentang Usaha Mikro Kecil dan Menengah. 